\title{
Capital-Skill Complementarity and Rigid Relative Wages Inference from the Business Cycle
}

Rose Skaksen, Jan; Sørensen, Anders

Document Version

Final published version

Publication date:

2004

\section{License \\ CC BY-NC-ND}

Citation for published version (APA):

Rose Skaksen, J., \& Sørensen, A. (2004). Capital-Skill Complementarity and Rigid Relative Wages: Inference from the Business Cycle. Copenhagen Business School, CBS. Working Paper / Department of Economics. Copenhagen Business School No. 10-2004

Link to publication in CBS Research Portal

\section{General rights}

Copyright and moral rights for the publications made accessible in the public portal are retained by the authors and/or other copyright owners and it is a condition of accessing publications that users recognise and abide by the legal requirements associated with these rights.

\section{Take down policy}

If you believe that this document breaches copyright please contact us (research.lib@cbs.dk) providing details, and we will remove access to the work immediately and investigate your claim. 


\title{
Department of Economics
}

Copenhagen Business School

Working paper 10-2004

CAPITAL-SKILL COMPLEMENTARITY AND RIGID RELATIVE WAGES: INFERENCE FROM THE BUSINESS CYCLE

\author{
Jan Rose Skaksen Anders Sørensen
}




\title{
Capital-Skill Complementarity and Rigid Relative Wages: Inference from the Business Cycle ${ }^{1}$
}

\author{
Jan Rose Skaksen \\ Copenhagen Business School \\ Anders Sørensen \\ Copenhagen Business School and CEBR
}

February 2004

\begin{abstract}
${ }^{1}$ We thank Per Krusell, Nikolaj Malchow-Møller, Richard Pomfret, two anonymous referees, and participants at the IZA conference on "European Integration and Labor Market Performance", at the EPRU conference on "Danish and International Economic Policy", and at the conference on "Globalization - Implications for Labour Market and Welfare Policies" for helpful comments. In particular we want to thank Jason Cummins and Giovanni Violante as well as Dale Jorgenson, Mun Ho and Kevin Stiroh for providing us with data for the United States. Bertel Schjerning provided efficient research assistance. Jan Rose Skaksen gratefully acknowledges financial support from the Danish Social Science Research Council. The usual disclaimer applies. Addresses: Skaksen, Department of Economics, Copenhagen Business School, Solbjerg Plads 3, 2000 Frederiksberg, Denmark; E-mail: jrs.eco@cbs.dk. Sørensen, Department of Economics and CEBR, Copenhagen Business School, Solbjerg Plads 3, 2000 Frederiksberg, Denmark; E-mail: as.eco@cbs.dk.
\end{abstract}




\begin{abstract}
The relative demand for skills has increased considerably in many OECD countries during recent decades. This development is potentially explained by capital-skill complementarity and high growth rates of capital equipment. When production functions are characterized by capital-skill complementarity, relative wages and employment of skilled labor are countercyclical because capital equipment is a quasifixed factor in the short run. The exact behavior of the two variables depends on relative wage flexibility. Relative wages are rigid in Denmark, implying that the employment share of skills should be countercyclical. The labor market is competitive in the United States and therefore relative wages of skilled labor are expected to be countercyclical. We find that the business cycle development of the two economies is consistent with capital-skill complementarity.
\end{abstract}

Keywords: capital-skill complementarity, relative wages, business cycle 


\section{Introduction}

The relative supply of skilled labor has increased considerably in many OECD countries during recent decades (see for example Machin and Van Reenen, 1998). In spite of these shifts, the relative wage of skilled labor has not deteriorated. Relative wages have even increased in the United States and the United Kingdom. In continental Europe relative wages have stayed constant or increased less dramatically as in the aforementioned countries. Why have relative wages increased or stayed constant during a period of large relative supply shifts of skills? The common answer is that large relative demand shifts towards skilled labor have taken place simultaneously with the supply shifts. It is generally agreed that the main driving mechanism behind these demand shifts is skill-biased technological change. Moreover, international outsourcing is attributed an important role (see e.g. Berman, Bound and Machin (1998) and Feenstra and Hanson (2003)).

Analyses of skill-biased technical changes usually assume that technological changes arise as a result of unobserved changes in the production function (see e.g. Katz and Murphy, 1992). More recently, Krusell et. al. (2000) associate technological changes with an observable factor, the growth rate of capital equipment. The central assumption for this explanation is capital-skill complementarity, which means that the elasticity of substitution between capital and unskilled labor is higher than the elasticity of substitution between capital and skilled labor. Consequently, skillbiased technological changes are interpreted as reflecting rapid growth in capital equipment combined with capital-skill complementarity.

Capital-skill complementarity has important implications for the business cycle behavior of relative demand for skilled labor because capital equipment is a quasifixed production factor. When aggregate demand falls, the production of final output is reduced through a decreasing use of factor inputs. Since capital is a quasifixed production factor and capital-skill complementarity prevails, the demand for unskilled labor decreases more than the demand for skilled labor. The opposite effect is present during an upturn. In other words, the relative demand for skills is countercyclical. The relative wage and employment of skilled labor are also countercyclical due to a positively sloping relative supply curve of skilled labor. The magnitude of these effects depends on the steepness of this curve. If it is flat, the business cycle effect on relative employment is considerable, whereas the effect on the relative wage is insignificant. If the supply curve is steep, the effect on the relative wage is important, whereas the effect on relative employment is unimportant.

In this paper, we investigate the business cycle behavior of relative wages and 
employment of skills and find it to be consistent with capital-skill complementarity. The empirical analysis is based on data for Denmark, which is interesting for two reasons. First, relative wages in Denmark have been almost constant for the past two decades. We argue that this is a result of labor market institutions where wages are determined by negotiations between unions and employers' organizations (see also Blau and Kahn, 1996). Accordingly, we expect the variability in employment shares of skilled labor over the business cycle to be countercyclical. This prediction is confirmed in the empirical analysis that links skill upgrading at the industry-level to the evolution of the macroeconomy, using panel data on industries through time. To our knowledge this finding is largely an unrecognized point in the literature on skill upgrading.

Second, the education system of Denmark includes a high variety of formal educations. For example, skilled labor includes workers with formal vocational education. This implies that three types of labor based on educational attainment can be distinguished: unskilled labor, skilled labor, and educated labor. The reason that we want to distinguish between unskilled and skilled labor is that these groups jointly constitute the majority of production workers. Consequently, it can be investigated whether capital-skill complementarity is more pronounced within the group of production workers compared to non-production workers. We do not find strong evidence for this since skills are upgraded over the business cycle for both groups of workers.

A final consideration is whether the established business cycle effect on the employment shares is robust to the inclusion of explanatory variables that capture ongoing skill upgrading. We find that the business cycle behavior is robust to the inclusion of explanatory variables capturing technological changes and outsourcing.

The empirical analysis for Denmark is compared to a corresponding analysis for the United States. This comparison is important because wage determination is different in the two economies, leading to different predictions of the business cycle behavior for the variables under investigation. While wages are determined by labor market institutions in Denmark, they are determined in a competitive labor market in the United States implying that relative wages are flexible. Therefore, the relative wage is expected to change over the business cycle, whereas the employment share may or may not vary significantly depending on the steepness of the relative supply curve. We establish that relative wages of skilled labor are countercyclical, whereas the employment shares of skilled labor vary insignificantly over the business cycle.

The paper proceeds as follows. In Section 2, we set up a simple theoretical model 
to illustrate the behavior of the relative demand and relative employment of skilled labor over the business cycle under capital-skill complementarity. In Section 3, we compare the labor market development in Denmark and the United States. Section 4 investigates to what extent the predictions of the theoretical model are consistent with the evidence for Denmark and the United States. Section 5 concludes.

\section{A simple theoretical model}

In this section, we set up a simple theoretical model to study labor market effects of business cycles and demand shifts between skilled and unskilled labor. Final output $(Y)$ is produced using unskilled labor $(L)$, skilled labor $(S)$ and capital $(K):^{1}$

$$
Y=\left[L^{\sigma}+\left(K^{\rho}+(a S)^{\rho}\right)^{\sigma / \rho}\right]^{1 / \sigma}, \quad \rho<\sigma<1 .
$$

The elasticities of substitution between capital and skilled labor and between unskilled labor and the aggregate of capital and skilled labor equal $1 /(1-\rho)$ and $1 /(1-\sigma)$, respectively. An important assumption is capital-skill complementarity, i.e. $1 /(1-\sigma)>1 /(1-\rho)$ or $\sigma>\rho$. $a$ is a productivity measure for skilled labor. Similar productivity variables for unskilled labor and capital could easily be introduced. For notational simplicity time subscripts are suppressed.

Our focus is relative inputs of the three production factors, implying that no assumptions concerning the final goods market are needed. Since the main purpose in the following is to analyze implications of business cycles, we implicitly assume that $Y$ depends on the demand for final goods. Finally, capital costs are assumed to be exogenous and equal to $r$.

In the following, we distinguish between the short and the long run. In the short run, capital is fixed, whereas it is fully flexible in the long run. Inputs of skilled and unskilled labor are always fully flexible. The assumptions defining the short run may seem restrictive, however, input of capital only needs to be less flexible then the input of the two labor types to obtain the qualitative results presented below.

\footnotetext{
${ }^{1}$ The model is based on two types of labor. However, $S$ could be interpreted as the total input of skilled and educated labor (i.e. a nested production function). For simplicity we refer to $K$ as capital even though capital-skill complementarity is related to capital equipment.
} 


\subsection{The long run}

Cost minimization implies that the relative marginal product between any two production factors equals the relative cost of the two production factors:

$$
\begin{aligned}
& \frac{\partial Y / \partial K}{\partial Y / \partial S}=\frac{r}{w^{S}}, \\
& \frac{\partial Y / \partial L}{\partial Y / \partial S}=\frac{w^{L}}{w^{S}} .
\end{aligned}
$$

where $w^{S}$ is the wage of skilled labor and $w^{L}$ is the wage of unskilled labor.

By using (1) and (2), capital input relative to effective skilled labor is derived as:

$$
\frac{K}{a S}=\left(\frac{a r}{w^{S}}\right)^{\frac{1}{\rho-1}}
$$

This implies that capital input increases relative to the input of skilled labor when the capital cost relative to the wage of skilled labor decreases.

Demand for skilled labor relative to unskilled labor is derived using (1), (3) and (4):

$$
\frac{S}{L}=\left(\frac{w^{L}}{w^{S}}\right)^{\frac{1}{1-\sigma}} a^{\frac{\sigma}{1-\sigma}}\left(\left(\frac{a r}{w^{S}}\right)^{\frac{\rho}{\rho-1}}+1\right)^{\frac{\sigma-\rho}{\rho(1-\sigma)}} .
$$

There are two channels through which relative demand for skilled labor increases. First, a reduction in capital costs increases relative demand for skilled labor:

$$
\frac{\partial(S / L)}{\partial r}<0
$$

When capital costs fall the use of capital increases. Since capital-skill complementarity applies, this in turn increases the demand for skilled labor relative to that of unskilled labor. Consequently, the negative sign of (6) requires capital-skill complementarity, i.e. $\sigma>\rho$. This is the hypothesis Krusell et. al. (2000) formulate to explain increasing relative demand for skilled labor. In this case, skill-biased technological changes are associated with observable factors.

Second, skill-biased technological changes associated with unobservable factors measured as an increase in $a$ also leads to increasing relative demand for skilled labor:

$$
\frac{\partial(S / L)}{\partial a}>0
$$


This result does not rest on the assumption of capital-skill complementarity where $\sigma>\rho$. The hypothesis that the increasing relative demand for skilled labor is a result of such changes in the production function may be found in e.g. Katz and Murphy (1992).

\subsection{The short run}

The capital stock is fixed in the short run, $K=\bar{K}$. Cost minimization implies that (3) also holds in the short run because inputs of skilled and unskilled labor are fully flexible. However, the relative demand for skilled labor changes to

$$
\frac{S}{L}=\left(\frac{w^{L}}{w^{S}}\right)^{\frac{1}{1-\sigma}} a^{\frac{\sigma}{1-\sigma}}\left(\left(\frac{\bar{K}}{a S}\right)^{\rho}+1\right)^{\frac{\sigma-\rho}{\rho(1-\sigma)}} .
$$

When the economy is in a downturn, the representative firm produces less than in the long run equilibrium (i.e. $Y$ decreases). In order to reduce production, factor inputs of $L$ and/or $S$ have to be reduced, see (1). According to (8), $S / L$ falls when $S$ is reduced, which implies that $L$ falls. Therefore, both $S$ and $L$ are reduced in a downturn, but the percentage fall in $L$ is larger that in $S$. By similar reasoning it follows that an upturn involves an increase in $S$ and $L$. Consequently, by using (8), we find that

$$
\frac{\partial(S / L)}{\partial Y}<0
$$

for constant wage rates, i.e. relative demand for skilled labor decreases during upturns and increases during downturns. This business cycle effect on relative demand for skills is generated by capital-skill complementarity, i.e. $\sigma>\rho$. Since the capital stock is fixed in the short run, changes in final output is to a larger extent achieved through changes in the input of unskilled labor.

Until now we have analyzed how the business cycle affects the relative demand for skilled labor. The effect on relative employment depends on the flexibility of relative wages. When relative wages are fixed, an increase in the relative demand for skilled labor gives rise to a similar increase in relative employment. Hence, the business cycle behavior in the relative demand for skilled labor is fully reflected in relative employment.

The business cycle behavior of the relative demand for skilled labor is fully

reflected in the relative wage when the relative supply of skills is independent of the 
relative wage, i.e. the relative supply curve is vertical. In this case, relative wages are fully flexible. The business cycle behavior of the relative demand for skills is partly reflected in the relative wage and partly in relative employment when the relative supply of skills depends on the relative wage, that is for a positively sloped but non-vertical relative supply curve. Hence, the change in the relative demand over the business cycle will be reflected in relative wages. Whether the relative employment of skills changes over the business cycle in the case of flexible relative wages is an empirical question.

\section{Labor market development in Denmark and the United States}

In the following the development of relative wages and employment shares for Denmark and the United States are presented. In particular we argue that relative wages in Denmark are rigid and that this is an outcome of labor market institutions. Relative wages of the United States, however, are flexible because of a competitive labor market.

We distinguish between three types of labor: unskilled labor, skilled labor, and educated labor. This choice is motivated by the education system of Denmark that includes a large variety of formal education. We want to distinguish between unskilled and skilled labor because these groups jointly constitute the majority of production workers. This enables us to study whether capital-skill complementarity is more pronounced within the group of production workers compared to non-production workers.

In Denmark, skilled labor includes workers with formal vocational education. Educated labor includes workers with short, medium, or long further education. ${ }^{2}$ The break down into skilled and educated labor is more arbitrary for the United States. We assume that educated labor includes workers that have obtained a bachelor degrees or higher, whereas skilled labor includes workers with some college education but no degree. ${ }^{3}$

\footnotetext{
${ }^{2}$ Vocational educations are a mix of schooling and training in firms. The typical duration is 3 years. Long further education corresponds to the ph.d. or the master level. Medium further education corresponds to the bachelor level. Short further educations are shorter and more practical than the bachelor level.

${ }^{3}$ To improve comparability with the data for the United States, Danish workers with short further educations could be grouped as skilled labor. We do not do this because unskilled workers
} 
Relative wages and employment shares for manufacturing and the private sector are presented below. Figure 1 presents employment shares for the three labor types.

\section{$<$ Figure 1 about here $>$}

The figure documents a decreasing trend in the employment share for unskilled labor and increasing trends for skilled and educated labor. This pattern is robust to sector and country choice. The only difference between the two countries is a larger employment share of educated labor in the United States and a larger share of skilled labor in Denmark. The documented development is consistent with the tendency for skill upgrading in most countries (see also Berman, Bound and Machin, 1998).

Figure 2 illustrates the development in the average wages of skilled and educated labor relative to the average wage of unskilled labor.

\section{$<$ Figure 2 about here $>$}

One would expect relative wages for skilled and educated labor to deteriorate, if the increasing employment shares of skilled and educated labor in both countries, as documented above, are due to supply shifts alone. It is evident from Figure 2 that neither country experiences deteriorating relative wages, which indicates that relative demand and supply shifts towards skilled labor have taken place simultaneously. The development of relative wages, however, has been quite different in the two countries. While relative wages have been almost constant in Denmark, especially, the relative wage of skilled labor, the United States have experienced increasing skill premium.

The relative wages of skilled and educated labor in the United States fall by $3.2 \%(1.8 \%)$ and $5.5 \%(5.5 \%)$, respectively, in manufacturing (the private sector) between 1990 and 1991. These falls coincide with recession in the U.S. economy (July 1990-March 1991) and increasing federal minimum wage (from $\$ 3.35$ in 1989 to $\$ 4.25$ in 1991). The nominal wage increased by $6.2 \%(5.6 \%)$ for unskilled labor, $3.0 \%(3.8 \%)$ for skilled labor, and $1.0 \%(0.2 \%)$ for educated labor in manufacturing (the private sector). We interpret these changes as indicating a large impact on the

and workers with formal vocation education jointly constitute the majority of production workers. This choice is without influence for the results presented in this paper. 
wage rate for unskilled labor in 1991. The minimum wage also increased in 1996 and 1997 (to $\$ 4.75$ in 1996 and to $\$ 5.15$ in 1997), however, these increases did not coincide with a recession.

Why have the relative wages of skilled and educated labor stayed almost constant in Denmark when they have increased in the United States? One possible explanation is that the relative supply shifts of skills in Denmark have been of a similar magnitude as the relative demand shifts, whereas the demand shifts in the United States have been larger than the supply shifts.

Acemoglu (2003) tests whether a simple supply and demand framework is able to explain different developments in relative wages across a number of OECD countries. It is assumed that the relative demand changes are of the same magnitude as in the United States, which is motivated by the argument that countries experience similar technological changes. Furthermore, it is assumed that employment equals the labor supply. Thereby, it is possible to determine relative wage changes consistent with the applied framework. These changes are then compared to the actual relative wage changes. It turns out that Danish relative wages are predicted to follow trends similar to the trends in the U.S. economy. This inconsistency between the predicted and the actual relative wage changes indicates that the Danish labor market is not competitive, and that the relative wages in Denmark is a result of specific labor market institutions.

One important labor market institution which may tend to give rise to constant relative wages is that more than 75 percent of the Danish labor force is organized in trade unions, and trade unions are involved in most wage negotiations in the Danish labor market (see e.g. Calmfors et al., 2001). On top of that, there are catch-up adjustments of unemployment and social benefits, which implies that these benefits follow the development in average wages. Since wages of unskilled labor tend to follow the development in unemployment and social benefits, it follows that relative wages tend to be constant.

If relative wages are rigid, changes in relative demand for skills that do not match the relative supply shifts will result in changing relative unemployment rates. The official unemployment rates for Denmark, however, show no tendency for increasing relative unemployment of unskilled labor in recent decades. ${ }^{4}$ One reason for this may be that the official rates are affected by policy changes concerning the classification of long term unemployed. In particular, early retirement schemes have been improved in Denmark in the period under investigation; especially for unskilled

\footnotetext{
${ }^{4}$ Nickell and Bell (1996) demonstrate that this is the case in a number of European countries.
} 
workers. Moreover, extensive possibilities for sabbatical leave from the labor market on unemployment benefits were introduced in the 1990s. Persons on leave are not registered as unemployed. As a consequence of this, we turn to the employment rate, defined as employment in full-time equivalents as a share of the population in the group. This is a more reliable indicator for the development in employment opportunities.

Figure 3 presents the difference in employment rates between skilled and unskilled labor as well as between educated and unskilled labor. ${ }^{5}$

\section{$<$ Figure 3 about here $>$}

The employment rates of skilled and educated labor display continuous increases relative to the employment rate of unskilled labor. This suggests that it has become increasingly difficult for unskilled labor to obtain employment compared to skilled and educated labor, ${ }^{6}$ which in turn supports the hypothesis that relative wages are rigid as a consequence of the institutional setting at the Danish labor market. Hence, labor market adjustments in Denmark take place through quantity adjustments.

There may be other explanations for increasing relative employment rates of skilled and educated labor. One possibility is composition effects: a decreasing share of the labor force is unskilled, and those who become skilled or educated tend to have higher participation rates. Hence, the population from which the pool of unskilled workers is drawn has a decreasing participation rate. Nevertheless, the development in relative wages and employment rates in the Danish labor market is consistent with relative wages being constant due to labor market institutions. Therefore, we proceed under this hypothesis.

\section{Empirical results}

In this section we present empirical results for increasing relative demand of skills. The main purpose is to study the relationship between skill upgrading and the

\footnotetext{
${ }^{5}$ The fraction of unskilled persons that is employed exhibits a negative trend during the period 1980-98. The fraction was about 65 in 1980.

${ }^{6}$ Figure 3 is based on persons between the age of 25 and 54 because persons born before 1921 are not distinguished according to educational background. Workers aged less than 25 are excluded in order to avoid confounding with variations in the age when educations are completed. The development illustrated in the figure is not a consequence of a changing age composition.
} 
business cycle. The robustness of the business cycle behavior of skill upgrading is addressed by including explanatory variables measuring ongoing effects on the relative demand for skills.

\subsection{Business cycle behavior of skill upgrading}

As discussed capital-skill complementarity has testable implications for the business cycle behavior of employment shares and relative wages of skills. When rigid relative wages apply as in the Danish economy, employment shares of skilled labor are expected to be countercyclical, whereas relative wages are independent of the cycle. When relative wages are flexible as in the U.S. economy, the relative wage of skills is expected to be countercyclical, and employment shares will vary less than in the case of rigid relative wages or maybe not at all.

\subsubsection{Aggregate data}

Table 1 reports simple correlation coefficients between changes in employment shares and growth rates in output (gross output and value added). The reported numbers are based on aggregate variables for manufacturing and the private sector. This gives a first indication as to whether labor markets in Denmark and the United States evolve as expected under capital-skill complementarity.

$<$ Table 1 about here>

It is evident that the correlation coefficients are consistent with the predictions. In Denmark the employment shares of unskilled labor is procyclical, whereas the employment share of skilled and educated labor are countercyclical. In the United States, there are no significant correlations. We do not consider correlations between relative wage changes and output growth for aggregate variables because relative wages are based on average sector wages, which are expected to be heavily influenced by composition effects over the business cycle.

It is unclear whether the established results are generated by shifts in labor demand within single industries or in labor demand shifts between industries. This concern is due to the fact that the presented correlation coefficients are based on aggregated data. Composition effects may be noticeable if either unskilled or skilled 
labor-intensive industries experience relative large labor demand shifts over the business cycle. If skill-capital complementarity is a general feature of industry production functions, we expect to observe countercyclical employment shares of skills within Danish industries as well as countercyclical skill premium in U.S. industries. To clarify this, skill upgrading over the business cycle within industries is investigated next.

\subsubsection{Panel data}

The relationships between employment shares and relative wages, respectively, and the business cycle are analyzed using the following equations for estimation purposes:

$$
d\left(\frac{L_{e, i, t}}{L_{i, t}}\right)=\alpha_{0}+\alpha_{1} d \log \left(\text { output }_{t}\right)+\varepsilon_{i, t}
$$

and

$$
d\left(\frac{w_{e, i, t}}{w_{i, t}}\right)=\beta_{0}+\beta_{1} d \log \left(\text { output }_{t}\right)+\nu_{i, t}
$$

where $L_{e, i, t}$ and $w_{e, i, t}$ denote employment and the wage rate of educational group $e$ (unskilled, skilled and educated labor) in industry $i$ at time $t . \quad L_{i, t}$ is total employment and $w_{i, t}$ is the average wage rate of industry $i$. output $t_{t}$ denotes final output. $\varepsilon_{i, t}$ and $\nu_{i, t}$ are error terms. The dependent variables are annual changes in the employment shares or relative wages for educational group $e$ in industry $i$ in period $t$.

The applied business cycle measure is the growth rate of the aggregate real gross output or value added for total manufacturing. We do not use industry-specific growth rates for final output since these are not necessarily good indicators for the business cycle. The public sector in Denmark is larger than in the United States. ${ }^{7}$ This implies that some services that are produced in the private sector in the United States are produced in the public sector in Denmark. Therefore, we only focus on manufacturing industries in the following.

The regressions are estimated including common intercepts and first-order autoregressive terms over industries. The first-order autoregressive terms are not reported in the tables below. We also estimated the regressions including industry-

\footnotetext{
${ }^{7}$ Public consumption amounts to $26 \%$ of GDP in Denmark, whereas it is only $18 \%$ in the United States.
} 
specific first-order autoregressive terms but these results are not presented since the qualitative results are insensitive to this choice. ${ }^{8}$

We draw on several data sources for Denmark. The labor market data are drawn from the IDA database from Statistics Denmark (2000), which gives a panel data set for 52 industries covering the period 1981-98. ${ }^{9}$ Data on aggregate value added and gross output for Danish manufacturing are drawn from input-output tables, Statistics Denmark (2002). For the United States we have data for 21 manufacturing industries for the period 1981 to 2000. The labor market data for the United States stem from Jorgenson, Ho and Stiroh (2002). Data on aggregate value added and gross output for U.S. manufacturing are taken from the National Income and Product Accounts (NIPA).

Table 2 reports results for regressions of the business cycle effect on employment shares.

$$
<\text { Table } 2 \text { about here }>
$$

The overall impression is that the results are consistent with the predicted business cycle behavior. The employment shares of unskilled labor are procyclical within Danish manufacturing industries, whereas those of skilled and educated labor are countercyclical. This result is independent of the choice of business cycle indicator. For U.S. manufacturing industries the general impression is that employment shares do not vary systematically over the business cycle.

Table 3 reports results for regressions of the business cycle effect on relative wages.

\section{$<$ Table 3 about here $>$}

\footnotetext{
${ }^{8}$ We use EViews for estimation purposes. EViews estimates AR models using nonlinear regression techniques. The nonlinear least squares estimates are asymptotically equivalent to maximum likelihood estimates and are asymptotically efficient. The coefficients on explanatory variables and the error terms are estimated simultaneously by applying a Marquardt nonlinear least squares algorithm to the transformed equation, see EViews4 User's Guide.

${ }^{9}$ The manufacturing sector is classified in 55 manufacturing industries. 3 industries are excluded because IDA data only permit that employment data are classified after 52 industries until 1993.
} 
In Denmark the relative wage of unskilled labor is countercyclical, whereas the relative wages of skilled and educated labor are procyclical. The relative wages for unskilled labor are procyclical and for skilled and educated labor countercyclical in the United States. Hence, the results for the United States confirm our expectations, whereas the results for Denmark do not.

At first the results for Denmark seem to be inconsistent with the expected business cycle development where theory predicts that relative wages should be invariant. In Table 3, however, the applied wages are average industry wages. It is well known that composition effects of the labor force over the business cycle affect average wages (see e.g. Solon, Barsky and Parker, 1994). In particular, less productive individuals enter the labor force in upturns. This composition effect is likely to be strongest among unskilled workers, and it tends to make the relative average wage of unskilled labor countercyclical. The regression results for Denmark are consistent with this explanation. ${ }^{10}$ As a consequence, we interpret the estimated results for Danish relative wages as being consistent with the hypothesis of capital-skill complementarity and rigid relative wages.

The relative wage regressions for the United States include a dummy variable for 1991. The dummy is introduced because the federal minimum wage increased in 1991 and moreover because 1991 was a recession year, as discussed in relation to Figure 2. The federal minimum wage was adjusted in 1990, 1991, 1996 and 1997. The qualitative results presented in Table 3 are insensitive to the inclusion of dummies for all four years. We did not include dummies in the relative employment regressions presented in Table 2 . When dummies are included the qualitative results are unaffected.

The results presented in Tables 2 and 3 make it possible to rule out that the established cyclical effects on skill upgrading are fully driven by compositional effects of manufacturing. Therefore, the panel data analysis brings further support for the hypothesis of capital-skill complementarity.

\subsubsection{Other considerations}

It is possible to distinguish between types of education in the Danish data as opposed to length of education that was applied in the analysis up to this point. Workers with

\footnotetext{
${ }^{10}$ The composition effects are probably also present in wage data for the United States. However, the opposite effects from relative demand shifts for skills are so strong that these drive the regression results; not the composition effects.
} 
technical education are typically employed as production workers, whereas workers with other educational background typically are employed as non-production workers. Consequently, it is of interest to distinguish between these education types because it provides information on the nature of capital-skill complementarity. Is capital-skill complementarity relevant for production workers (i.e. technical skilled or educated labor), non-production workers (i.e. non-technical skilled or educated labor) or both?

Table 4 reports results for regressions of the business cycle effect on employment shares of different types of skilled and educated labor. We only present regressions including the growth rate of aggregate gross output since this is our preferred measure for the business cycle. Similar results are established when the growth rate of value added is applied.

$<$ Table 4 about here $>$

The employment shares of both types of labor, skilled and educated, are countercyclical. However, the business cycle effect is numerically larger and more significant for labor with technical education. This suggests that the capital-skill complementarity is stronger for production workers than for non-production workers. However, the estimated business cycle effects are not significantly different across labor types. Hence, we do not find that the business cycle effect from capital-skill complementarity is stronger for production workers compared to non-production workers.

\subsection{Long run skill upgrading}

The focal point of this paper is the business cycle behavior of skill upgrading. The finding that skill upgrading varies over the business cycle does not explain the underlying causes for skill upgrading. In other words, it does not elucidate mechanisms that drive ongoing changes in relative labor demand for skills. In the following, we investigate whether the business cycle effect is robust to the inclusion of explanatory variables that capture ongoing skill upgrading.

A number of hypotheses explain skill upgrading in the literature: international outsourcing (see e.g. Feenstra and Hanson, 2003), skill-biased technological changes in the form of increasing efficiency of skilled and educated labor (see e.g. Katz and Murphy, 1992), skill-biased technological changes associated with growth in capital 
equipment combined with capital-skill complementarity (see e.g. Krusell et. al, 2000). It is of interest to investigate the robustness of the business cycle effect when these long run effects are taken into consideration.

We include explanatory variables for the above mentioned effects in the regression analysis. Two measures of international outsourcing are included: a narrow measure (out1) and a broad measure (out2). The narrow measure is defined as import of intermediate goods from the same foreign industry relative to gross output of the industry. The broad measure is defined as import of intermediate goods from other foreign manufacturing industries relative to gross output of the industry. The data on international outsourcing and gross output are based on input-output tables, Statistics Denmark (2002).

It is more difficult to procure measures for skill-biased technological changes. In the literature, different variables have been used to capture the increasing efficiency of skilled and educated labor. Autor, Katz, and Krueger (1998) investigate whether the diffusion of computers and related technologies is an important source of changes in the relative demand of skills and thereby in the relative efficiency of skilled labor. Machin and Van Reenen (1998) use R\&D intensities to explain skill upgrading.

Good measures for skill-biased technological changes are not available for Denmark. ${ }^{11}$ Therefore, we turn to sources for the United States. More precisely, we apply the measure of technological improvements in equipment and software reported in Cummins and Violante (2002). ${ }^{12}$ This provides industry-specific indexes for embodied technological progress. The measure builds on the development in quality adjusted prices of investment goods in the United States. However, it seems reasonable to assume relatively fast spread of technology to similar industries in other countries. ${ }^{13}$

\footnotetext{
${ }^{11}$ Industry-specific data on computers (hardware and software) do not exist for Denmark. R\&D data that are compatible with the labor market data, i.e. industry-structure ISIC Revision 3, only exist for 15 industries over the period 1987-98.

${ }^{12}$ The indexes for technological changes are determined by a Tornquist procedure to aggregate the asset-level price indexes into a quality-adjusted price index for equipment and software. The weights for this procedure are industry-specific nominal investment shares of each asset for each year. We tried to develop indexes that applied to the Danish economy by using Danish industryspecific nominal investment shares. This was not possible for two reasons. First, industry-specific investments are not grouped by asset type but rather by delivering industry. Second, industryspecific investments grouped by delivering industries only exist for the period 1993-98.

${ }^{13}$ Industry-specific technological changes are available for 21 manufacturing industries. These indexes are distributed between the 52 Danish manufacturing industries. Hence, closely related industries are assumed to experience similar technological changes.
} 
The applied indicator for skill-biased technological changes is related to investments in capital equipment. It is assumed that capital equipment has to be installed and that this installation takes time. Therefore, the variable enters as a lagged value in the regressions, implying that investments made last period affect relative demand for skills in the current period.

Table 5 reports results for regressions on employment shares when measures of international outsourcing and skill-biased technological changes are included in addition to the business cycle effect.

$<$ Table 5 about here $>$

The most important result is that the business cycle effects on employment shares are robust to the inclusion of other explanatory variables. The employment shares of unskilled labor remain procyclical, whereas the employment shares of skilled and educated labor are countercyclical.

The narrow measure of international outsourcing tends to increase employment shares of educated labor, whereas the broad measure is without influence on the employment shares. Even though the measure of skill-biased technological changes is an imperfect measure, the results are to some degree consistent with our expectations. Technological changes lead to skill upgrading in the sense that the employment share of educated labor increases, whereas the combined employment share of skilled and unskilled labor is reduced.

The purpose of including explanatory variables that capture ongoing skill upgrading is to address the robustness of the business cycle effect on the relative demand for skills. The main impression of this analysis is that the business cycle effect is robust to the inclusion of these variables.

\section{Conclusion}

The relative demand for skilled labor has increased dramatically in many OECD countries during recent decades. Krusell et. al. (2000) argue that this development is a result of accelerating investments in capital equipment combined with capital-skill complementarity. If production functions are characterized by capitalskill complementarity, the development in employment shares and relative wages for 
skills are countercyclical since capital equipment is a quasi-fixed factor in the short run. In this paper, we find that the business cycle development in relative wages and employment shares of skills are consistent with the hypothesis of capital-skill complementarity. In Denmark, where relative wages are rigid, employment shares of unskilled labor are procyclical, whereas employment shares of skilled and educated labor are countercyclical. In the United States, where relative wages are flexible, the relative wages of unskilled labor are procyclical, whereas they are countercyclical for skilled and educated labor. These empirical results are consistent with production functions characterized by capital-skill complementarity.

The analysis is related to the literature on business cycle variability of real wages. Until the early 1990s, the general view was that real wages are acyclical or slightly procyclical, but in more recent work it has been documented that this is a result of measurement problems. Using microdata, wages are found to be significantly procyclical (see e.g. Bils, 1985 and Solon, Barsky and Parker, 1994). We do not have anything to add on the cyclicality of real wages and the employment level since our focal point is relative wages and employment shares of different skill groups.

There may be other reasons for countercyclical relative demand for skills than capital-skill complementarity. Firm-specific human capital of skilled labor (see e.g. Becker, 1964) and hiring and firing costs that are higher for skilled labor than unskilled labor (see e.g. Bentolila and Bertola, 1990) may give rise to labor hoarding in downturns of especially skilled and educated labor. This in turn implies that the relative demand of skilled and educated labor will be countercyclical. However, the main point made in this paper is that the business cycle evidence for two very different economies are consistent with capital-skill complementarity. 


\section{References}

[1] Acemoglu, D., 2003, Cross-Country Inequality Trends, Economic Journal, 113, 121-149

[2] Autor, D.H., L.F. Katz, and A.B. Krueger, 1998, Computing Inequality: Have Computers Changed the Labor Market?, Quarterly Journal of Economics, 113 (4), 1169-1213

[3] Becker, G.S., 1964, Human Capital: A Theoretical and Empirical Analysis with Special Reference to Education. New York: Columbia University Press.

[4] Berman, E., J. Bound and Z. Griliches, 1994, Changes in the Demand for Skilled Labor within U.S. Manufacturing: Evidence from the Annual Survey of Manufactures, Quarterly Journal of Economics, 104, 367-398.

[5] Berman, E., J. Bound, and S. Machin, 1998, 'Implications of Skill-Biased Technical Changes: International Evidence', Quarterly Journal of Economics, 12451280.

[6] Bentolila, S. and G. Bertola, 1990, Firing Costs and Labour Demand: How Bad is Eurosclerosis, Review of Economic Studies, 57, 381-402.

[7] Bils, M., 1985, Real wages over the business cycle: evidence from panel data, Journal of Political Economy, 93, 666-689.

[8] Blau, F.D. and L.M. Kahn, 1996, International Differences in Male Wage Inequality: Institutions versus Market Forces, Journal of Political Economy, 104, 791-837.

[9] Calmfors, L.A., A. Booth, M. Burda, D. Checci, R. Naylor and J. Visser, 2001, The Future of Collective Bargaining in Europe. In Boeri, T., A. Brugiavini and L. Calmfors (eds.): The Role of Unions in the Twenty-First Century. Oxford University Press, Oxford

[10] Cummins, J.G. and G.L. Violante, 2002, Investment-Specific Technical Change in the United States (1947-2000): Measurement and Macroeconomic Consequences, Review of Economic Dynamics, 5, 243-284.

[11] Feenstra, R.C. and G.D. Hanson, 2003, Global Production Sharing and Rising Inequality: A Survey of Trade and Wages, in Kwan Choi and James Harrigan, eds., Handbook of International Trade, Basil Blackwell. 
[12] Greenwood, J., Z. Hercowitz, and P. Krusell, 1997, Long-Run Implications of Investment-Specific Technological Change, American Economic Review, 87, 342-362

[13] Jorgenson, D., M. Ho and K. Stiroh, 2002, Growth of U.S. Industries and Investments in Information Technology and Higher Education, Harvard University, Mimeo.

[14] Katz, L.F. and K.M. Murphy, 1992, Changes in Relative Wages, 1963-1987: Supply and Demand Factors, Quarterly Journal of Economics, 107, 35-78.

[15] Krusell, P., L.E. Ohanian, J.-V. Ríos-Rull, and G.L. Violante, 2000, 'CapitalSkill Complementarity and Inequality: A Macroeconomic Analysis', Econometrica, 1029-1054

[16] Machin, S., and J. Van Reenen, 1998, Technology and Changes in Skill Structure: Evidence from Seven OECD Countries, Quarterly Journal of Economics, 113 (4), 1215-1244

[17] Nickell, S. and B. Bell, 1996, Changes in the Distribution of Wages and Unemployment in OECD countries, American Economic Review, 86, 302-308.

[18] Solon, G., R. Barsky and J. Parker, 1994, Measuring the Cyclicality of Real Wages: How important is Composition Bias, Quarterly Journal of Economics, 109, 1-26.

[19] Statistics Denmark, 2000, 'IDA Database' Copenhagen

[20] Statistics Denmark, 2000, 'Input-Output Tables', Copenhagen 
Figure 1: $\quad$ Employment Shares

Manufacturing, Denmark

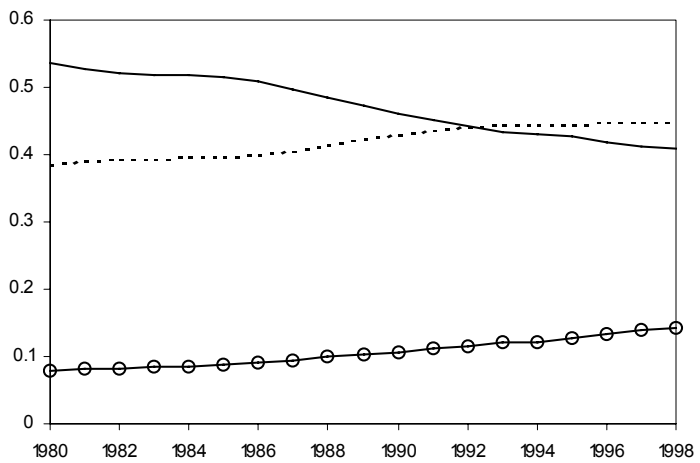

$\longrightarrow \mathrm{LV} L \mathrm{~L} \ldots . . \mathrm{L} 2 / \mathrm{L} \longrightarrow \mathrm{O} \mathrm{L} 3 / \mathrm{L}$

Private Sector, Denmark

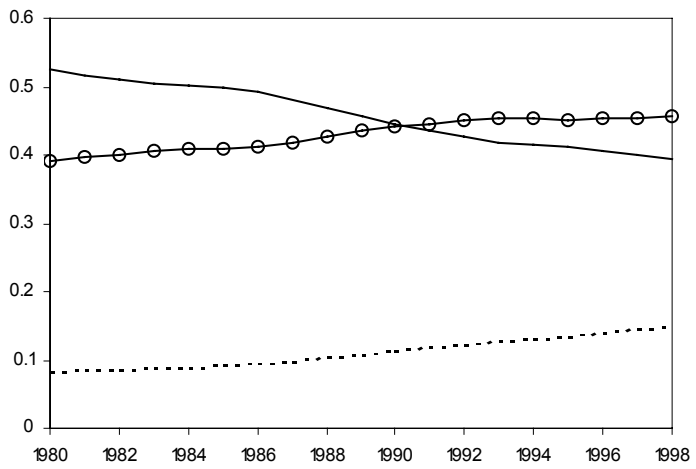

Manufacturing, USA

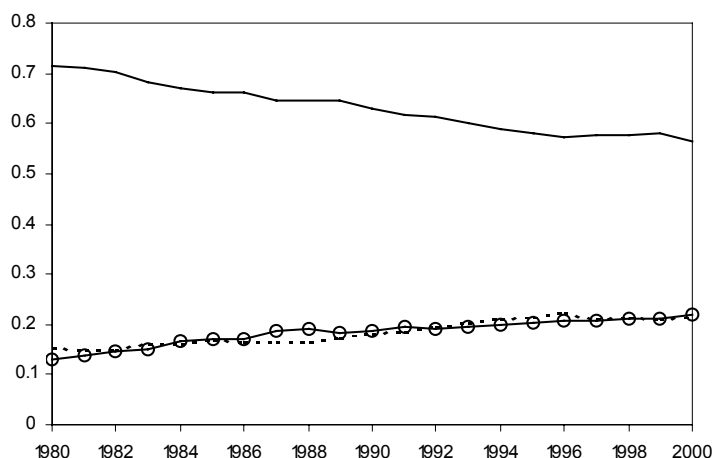

$\longrightarrow \mathrm{LV} L \ldots . . . \mathrm{L} 2 / \mathrm{L} \longrightarrow \mathrm{O}^{\mathrm{L} 3 / \mathrm{L}}$

Private Sector, USA

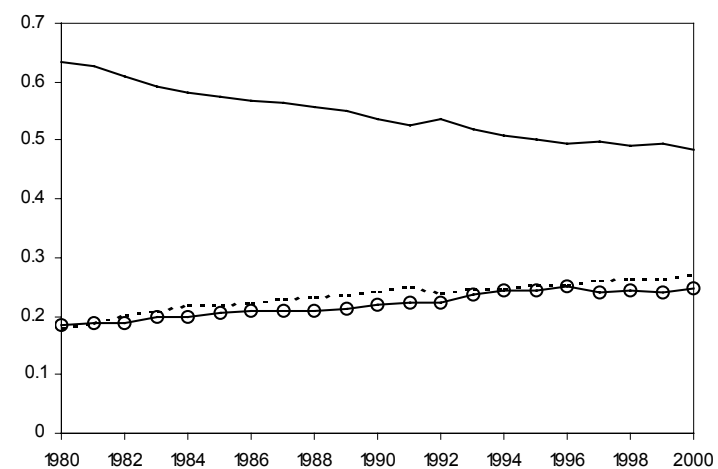

Note: Le/L: Employment in educational group $e$ relative to total employment (Full-time equivalents), 1: unskilled labor, 2: skilled labor, 3: educated labor.

Source: IDA, Statistics Denmark (2000) and Jorgenson, Ho, and Stiroh (2002) 
Figure 2: $\quad$ Relative Wages Indexes

Manufacturing, Denmark

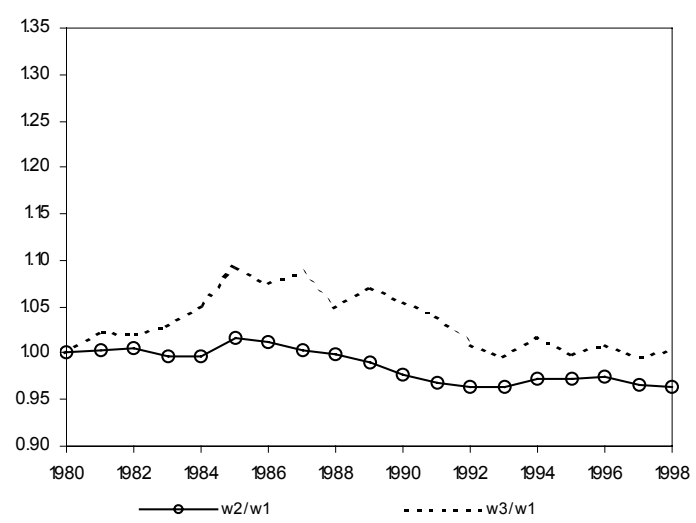

Private Sector, Denmark

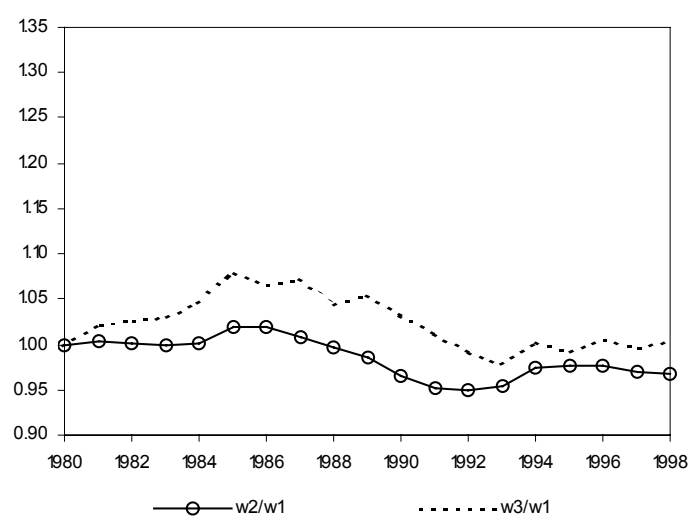

Manufacturing, USA

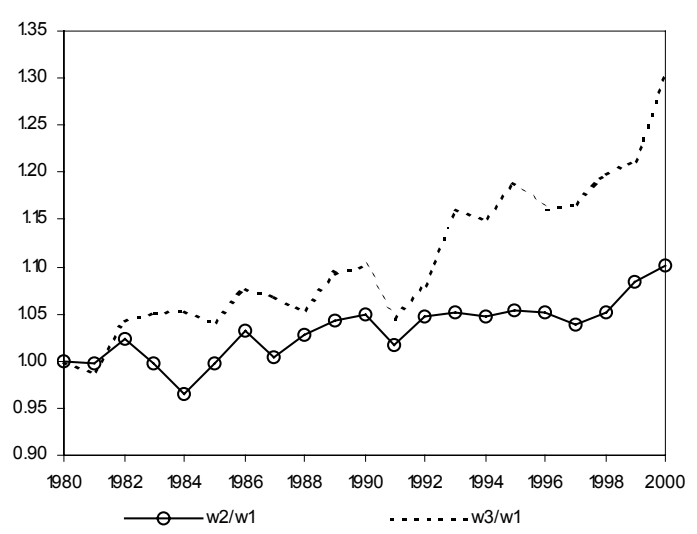

Private Sector, USA

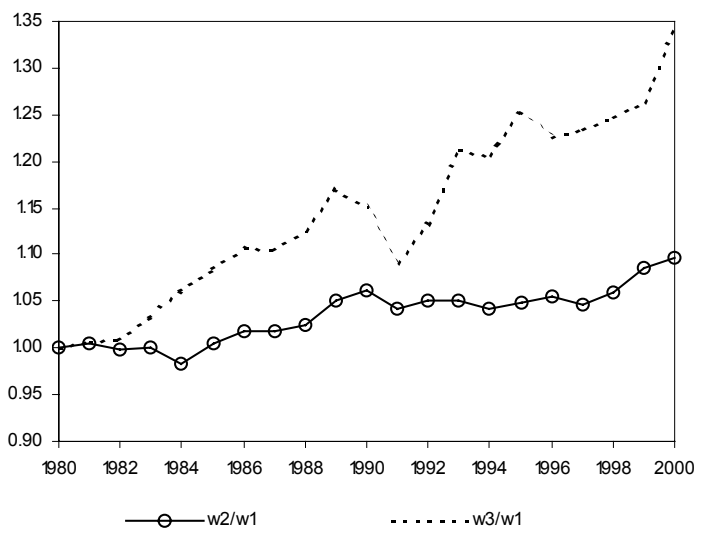

Note: $w_{\mathrm{e}} / w_{1}$ : Average wage rate in educational group $e$ relative to average wage rate of unskilled labor, 1 : unskilled labor, 2: skilled labor, 3: educated labor.

Source: IDA, Statistics Denmark (2000) and Jorgenson, Ho, and Stiroh (2002) 
Figure 3: $\quad$ Differences in Employment Rates, Denmark 1980-1998

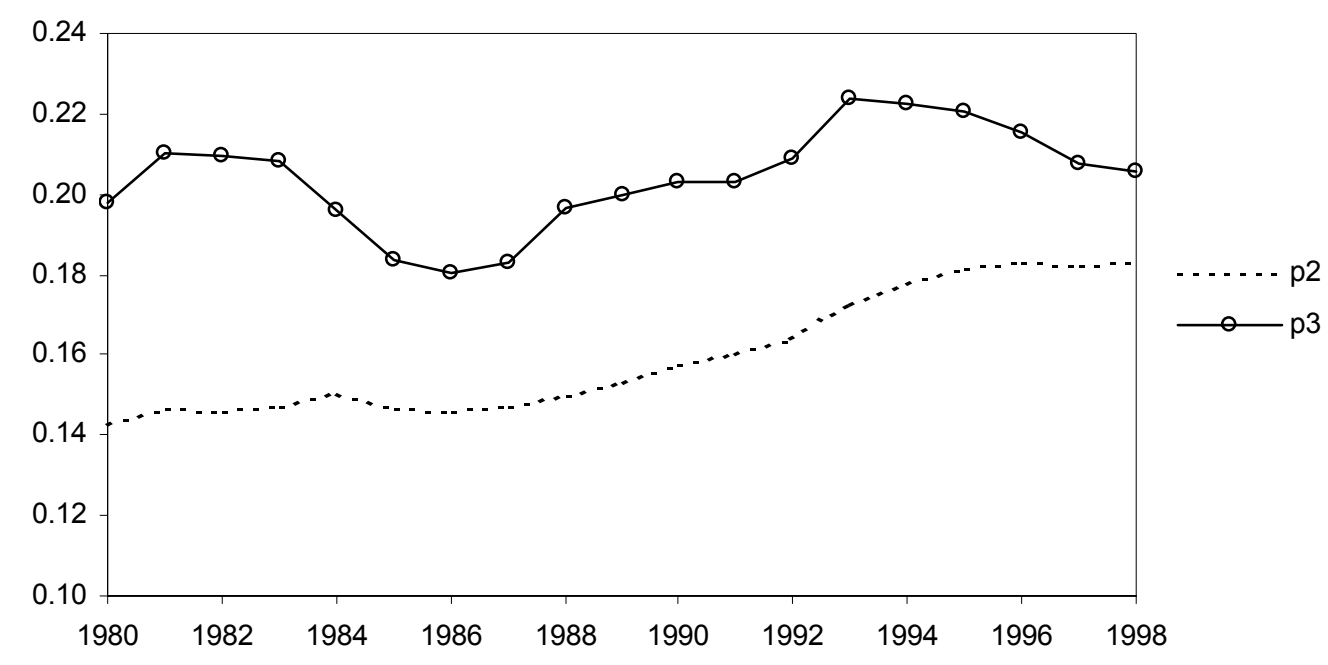

Note: The employment rate is defined as employment in full-time equivalents as a share of the population. pi: difference in employment rates between education category $i$ and unskilled labor. 2: skilled labor, 3: educated labor. The population covers persons aged 25-54.

Source: IDA, Statistics Denmark (2000) 
Table 1: $\quad$ Output Growth and Skill Upgrading, Correlation Coefficients, 1980-1998

\begin{tabular}{|lll|lll|}
\hline & & & $\mathrm{d}(L 1 / L)$ & $\mathrm{d}(L 2 / L)$ & $\mathrm{d}(L 3 / L)$ \\
\hline \multirow{2}{*}{ Denmark } & \multirow{2}{*}{ Gross Output } & Private Sector & $0.59^{* *}$ & $-0.52^{* *}$ & -0.30 \\
& & Manufacturing & $0.71^{* * *}$ & $-0.58^{* *}$ & $-0.51^{* *}$ \\
& \multirow{4}{*}{ Value Added } & Private Sector & $0.54^{* *}$ & $-0.50^{* *}$ & -0.22 \\
& & Manufacturing & $0.63^{* * *}$ & $-0.52^{* *}$ & $-0.43^{*}$ \\
\hline \multirow{2}{*}{ USA } & \multirow{2}{*}{ Gross Output } & Private Sector & - & - & - \\
& & Manufacturing & 0.11 & -0.18 & 0.05 \\
& \multirow{4}{*}{ Value Added } & Private Sector & 0.35 & -0.17 & -0.32 \\
& & Manufacturing & -0.08 & -0.18 & 0.31 \\
\hline
\end{tabular}

Notes: ${ }^{* * *}$ significant at 1 pct. level, ${ }^{* *}$ significant at 5 pct. level, and ${ }^{*}$ significant at 10 pct. level.

Source: IDA, Statistics Denmark (2000), and Jorgenson, Ho, and Stiroh (2002) 
Table 2: $\quad$ Regressions for Employment Shares of Unskilled, Skilled, and Educated Labor, Annual Changes

\begin{tabular}{|c|c|c|c|c|c|c|}
\hline DENMARK, 1981-1998 & $\mathrm{d}(L 1 / L)$ & $\mathrm{d}(L 2 / L)$ & $\mathrm{d}(L 3 / L)$ & $\mathrm{d}(L 1 / L)$ & $\mathrm{d}(L 2 / L)$ & $\mathrm{d}(L 3 / L)$ \\
\hline Constant & $\begin{array}{l}-0.009^{* * *} \\
(16.09)\end{array}$ & $\begin{array}{l}0.005^{* * *} \\
(9.50)\end{array}$ & $\begin{array}{l}0.005^{* * *} \\
(9.93)\end{array}$ & $\begin{array}{l}-0.008^{* * *} \\
(15.84)\end{array}$ & $\begin{array}{l}0.004^{* * *} \\
(8.70)\end{array}$ & $\begin{array}{l}0.004^{* * *} \\
(10.59)\end{array}$ \\
\hline $\mathrm{d} \log (\mathrm{GO})$ & $\begin{array}{l}0.104^{* * *} \\
(5.58)\end{array}$ & $\begin{array}{l}-0.059^{* * *} \\
(3.50)\end{array}$ & $\begin{array}{l}-0.050^{* * *} \\
(3.51)^{*}\end{array}$ & & & \\
\hline $\operatorname{dlog}(\mathrm{VA})$ & & & & $\begin{array}{l}0.057^{* * *} \\
(4.30) \\
\end{array}$ & $\begin{array}{l}-0.030^{* *} \\
(2.39) \\
\end{array}$ & $\begin{array}{l}-0.030^{* * *} \\
(3.00) \\
\end{array}$ \\
\hline R-squared & 0.0333 & 0.0190 & 0.0178 & 0.0215 & 0.0127 & 0.0150 \\
\hline Adjusted R-squared & 0.0311 & 0.0168 & 0.0156 & 0.0193 & 0.0105 & 0.0128 \\
\hline Durbin-Watson stat & 1.93 & 2.05 & 1.90 & 1.92 & 2.05 & 1.90 \\
\hline Total panel (balanced) observations: & 884 & 884 & 884 & 884 & 884 & 884 \\
\hline USA, 1981-2000 & $\mathrm{d}(L 1 / L)$ & $\mathrm{d}(L 2 / L)$ & $\mathrm{d}(L 3 / L)$ & $\mathrm{d}(L 1 / L)$ & $\mathrm{d}(L 2 / L)$ & $\mathrm{d}(L 3 / L)$ \\
\hline Constant & $\begin{array}{l}-0.006^{* * *} \\
(8.14)\end{array}$ & $\begin{array}{l}0.005^{* * *} \\
(8.22)\end{array}$ & $\begin{array}{l}0.003^{* * *} \\
(4.83)\end{array}$ & $\begin{array}{l}-0.006^{* * *} \\
(8.26)\end{array}$ & $\begin{array}{l}0.004^{* * *} \\
(7.79)\end{array}$ & $\begin{array}{l}0.003^{* * *} \\
(4.65)\end{array}$ \\
\hline $\mathrm{d} \log (\mathrm{GO})$ & $\begin{array}{r}-0.017 \\
(0.85)\end{array}$ & $\begin{array}{l}-0.033^{* *} \\
(2.30)\end{array}$ & $\begin{array}{l}0.012 \\
(0.80)\end{array}$ & & & \\
\hline $\mathrm{d} \log (\mathrm{VA})$ & & & & $\begin{array}{r}-0.023 \\
(1.51) \\
\end{array}$ & $\begin{array}{r}-0.018 \\
(1.60) \\
\end{array}$ & $\begin{array}{l}0.022^{*} \\
(1.72) \\
\end{array}$ \\
\hline R-squared & 0.0048 & 0.0523 & 0.0094 & 0.0099 & 0.0447 & 0.0186 \\
\hline Adjusted R-squared & -0.0003 & 0.0475 & 0.0044 & 0.0049 & 0.0399 & 0.0136 \\
\hline Durbin-Watson stat & 1.87 & 2.15 & 2.05 & 1.86 & 2.13 & 2.04 \\
\hline Total panel (balanced) observations: & 399 & 399 & 399 & 399 & 399 & 399 \\
\hline
\end{tabular}

Note: $\quad$ Dependent variable: $L_{\mathrm{e}, \mathrm{i}, \mathrm{t}} / L_{\mathrm{i}, \mathrm{t}}$ refers to employment share for educational group $e$, industry $i$ at time $t$. Explanatory variables: $\log (\mathrm{GO})$ and $\log (\mathrm{VA})$ refer to the $\log$ of gross output and value added, respectively, in total manufacturing. All regressions include a first order autoregressive process (nor reported). $t$-statistics are White Heteroscedasticity consistent. ${ }^{* * *}$ significant at 1 pct. level, ${ }^{* *}$ significant at 5 pct. level, and ${ }^{*}$ significant at 10 pct. level.

Source: IDA, Statistics Denmark (2000), and Jorgenson, Ho, and Stiroh (2002) 
Table 3: $\quad$ Regressions for Relative Wages for Unskilled, Skilled, and Educated

\section{Labor, Annual Changes}

\begin{tabular}{|c|c|c|c|c|c|c|}
\hline DENMARK, 1981-1998 & $\mathrm{d}(w 1 / w)$ & $\mathrm{d}(w 2 / w)$ & $\mathrm{d}(w 3 / w)$ & $\mathrm{d}(w 1 / w)$ & $\mathrm{d}(w 2 / w)$ & $\mathrm{d}(w 3 / w)$ \\
\hline Constant & $\begin{array}{l}0.000 \\
(0.08)\end{array}$ & $\begin{array}{l}-0.005^{* * *} \\
(8.64)\end{array}$ & $\begin{array}{l}-0.012^{* * *} \\
(7.06)\end{array}$ & $\begin{array}{r}-0.001 \\
(1.28)\end{array}$ & $\begin{array}{l}-0.004^{* * *} \\
(8.16)\end{array}$ & $\begin{array}{l}-0.010^{* * *} \\
(6.20)\end{array}$ \\
\hline $\mathrm{d} \log (\mathrm{GO})$ & $\begin{array}{l}-0.071^{* * *} \\
(3.93)\end{array}$ & $\begin{array}{l}0.0711^{* * *} \\
(3.59)\end{array}$ & $\begin{array}{l}0.500 \text { *** } \\
(8.01)\end{array}$ & & & \\
\hline $\mathrm{d} \log (\mathrm{VA})$ & & & & $\begin{array}{l}-0.040^{* * *} \\
(3.06) \\
\end{array}$ & $\begin{array}{l}0.030^{* *} \\
(2.08)\end{array}$ & $\begin{array}{l}0.357^{* * *} \\
(7.92)\end{array}$ \\
\hline R-squared & 0.0724 & 0.1143 & 0.1214 & 0.0664 & 0.1064 & 0.1245 \\
\hline Adjusted R-squared & 0.0703 & 0.1123 & 0.1194 & 0.0643 & 0.1043 & 0.1225 \\
\hline Durbin-Watson stat & 2.24 & 2.15 & 2.15 & 2.23 & 2.14 & 2.15 \\
\hline Total panel (balanced) observations: & 884 & 884 & 884 & 884 & 884 & 884 \\
\hline USA, 1981-2000 & $\mathrm{d}(w 1 / w)$ & $\mathrm{d}(w 2 / w)$ & $\mathrm{d}(w 3 / w)$ & $\mathrm{d}(w 1 / w)$ & $\mathrm{d}(w 2 / w)$ & $\mathrm{d}(w 3 / w)$ \\
\hline Constant & $\begin{array}{l}-0.010^{* * *} \\
(14.80)\end{array}$ & $\begin{array}{l}0.008^{* * *} \\
(4.32)\end{array}$ & $\begin{array}{l}0.020^{* * *} \\
(5.45)\end{array}$ & $\begin{array}{l}-0.009^{* * *} \\
(14.52)\end{array}$ & $\begin{array}{l}0.008^{* * *} \\
(4.72)\end{array}$ & $\begin{array}{l}0.022^{* * *} \\
(6.38)\end{array}$ \\
\hline $\mathrm{d} \log (\mathrm{GO})$ & $\begin{array}{l}0.096^{* * *} \\
(6.50)\end{array}$ & $\begin{array}{l}-0.332^{* * *} \\
(7.92)\end{array}$ & $\begin{array}{l}-0.269^{* * *} \\
(3.42)\end{array}$ & & & \\
\hline dlog(VA) & & & & $\begin{array}{l}0.068^{* * *} \\
(5.57)\end{array}$ & $\begin{array}{l}-0.303^{* * *} \\
(8.40)\end{array}$ & $\begin{array}{l}-0.285^{* * *} \\
(4.50)\end{array}$ \\
\hline d91 & $\begin{array}{l}0.024^{* * *} \\
(6.43)\end{array}$ & $\begin{array}{l}-0.040^{* * *} \\
(7.53) \\
\end{array}$ & $\begin{array}{l}-0.100^{* * *} \\
(4.94)\end{array}$ & $\begin{array}{l}0.024^{* * *} \\
(6.36)\end{array}$ & $\begin{array}{l}-0.044^{* * *} \\
(8.16)\end{array}$ & $\begin{array}{l}-0.10^{* * *} \\
(5.26)\end{array}$ \\
\hline R-squared & 0.1963 & 0.1918 & 0.1569 & 0.1866 & 0.2287 & 0.1738 \\
\hline Adjusted R-squared & 0.1902 & 0.1857 & 0.1505 & 0.1804 & 0.2228 & 0.1675 \\
\hline Durbin-Watson stat & 2.00 & 2.15 & 2.08 & 1.97 & 2.18 & 2.06 \\
\hline Total panel (balanced) observations: & 399 & 399 & 399 & 399 & 399 & 399 \\
\hline
\end{tabular}

Note: Dependent variable: $w_{\mathrm{e}, \mathrm{i}, t} / w_{\mathrm{i}, \mathrm{t}}$ refers to the relative wage for educational group $e$, industry $i$ at time $t$. Explanatory variables: $\log (\mathrm{GO})$ and $\log (\mathrm{VA})$ refer to the $\log$ of gross output and value added, respectively, in total manufacturing, d91 is a dummy variable equal to 1 in 1991 and 0 for other years. All regressions include a first order autoregressive process (nor reported). $t$-statistics are White Heteroscedasticity consistent. ${ }^{* * *}$ significant at 1 pct. level, ${ }^{* *}$ significant at 5 pct. level, and ${ }^{*}$ significant at 10 pct. level.

Source: IDA, Statistics Denmark (2000), and Jorgenson, Ho, and Stiroh (2002) 
Table 4: $\quad$ Regressions for Employment Shares of Technical and Non-technical Skilled Labor and Technical and Non-technical Educated Labor in Denmark, Annual Changes, 1981-98

\begin{tabular}{lcccc} 
& $\mathrm{d}(L 2$, tech $/ L)$ & $\mathrm{d}(L 2$, non-tech $/ L)$ & $\mathrm{d}(L 3$, tech $/ L)$ & $\mathrm{d}(L$ 3,non-tech $/ L)$ \\
\hline Constant & $0.004^{* * *}$ & $0.001^{* * *}$ & $0.003^{* * *}$ & $0.002^{* * *}$ \\
& $(6.44)$ & $(2.70)$ & $(6.64)$ & $(8.16)$ \\
$\mathrm{d} \log (\mathrm{GO})$ & $-0.040^{* *}$ & $-0.019^{*}$ & $-0.026^{* *}$ & $-0.014^{*}$ \\
& $(2.34)$ & $(1.71)$ & $(2.28)$ & $(1.68)$ \\
\hline & & & & \\
R-squared & 0.0123 & 0.0093 & 0.0071 & 0.0219 \\
Adjusted R-squared & 0.0100 & 0.0071 & 0.0043 & 0.0197 \\
Durbin-Watson stat & 2.03 & 2.05 & 1.78 & 2.11 \\
Total panel (balanced) observations: & 884 & 884 & 884 & 884 \\
\hline
\end{tabular}

Note: Dependent variable: $L_{\mathrm{e}, \mathrm{i}, \mathrm{t}} / L_{\mathrm{i}, \mathrm{t}}$ refers to the employment share for educational group $e$, industry $i$ at time $t$. Explanatory variables: $\log (\mathrm{GO})$ refers to the $\log$ of gross output in total manufacturing. All regressions include a first order autoregressive process (nor reported). $t$-statistics are White Heteroscedasticity consistent. ${ }^{* * *}$ significant at 1 pct. level, ${ }^{* *}$ significant at 5 pct. level, and ${ }^{*}$ significant at 10 pct. level.

Source: IDA, Statistics Denmark (2000) 
Table 5: $\quad$ Regressions for Employment Shares of Unskilled, Skilled, and Educated Labor in Denmark, Annual Changes, 1981-98

\begin{tabular}{lccc} 
& $\mathrm{d}(L 1 / L)$ & $\mathrm{d}(L 2 / L)$ & $\mathrm{d}(L 3 / L)$ \\
\hline Constant & $-0.009^{* * *}$ & $0.005^{* * *}$ & $0.004^{* * *}$ \\
$\mathrm{~d} \log (\mathrm{GO})$ & $(14.16)$ & $(9.18)$ & $(7.18)^{* * *}$ \\
& $0.111^{* * *}$ & $-0.057^{* * *}$ & $-0.059^{* * *}$ \\
$\mathrm{~d}($ out1) & $(5.52)$ & $(3.20)$ & $(3.94)^{* * *}$ \\
& -0.028 & -0.041 & $0.067^{* * *}$ \\
$\mathrm{~d}($ out2) & $(0.90)$ & $(1.60)$ & $(3.08)$ \\
& -0.040 & $0.048^{*}$ & -0.010 \\
technology change & $(1.63)$ & $(1.86)$ & $(0.41)$ \\
& -0.005 & $-0.015^{*}$ & $0.019^{* *}$ \\
\hline & $(0.52)$ & $(1.76)$ & $(2.11)$ \\
R-squared & & & \\
Adjusted R-squared & 0.0384 & 0.0349 & 0.0389 \\
Durbin-Watson stat & 0.0328 & 0.0293 & 0.0333 \\
Total panel (balanced) observations: & 1.93 & 2.05 & 1.90 \\
\hline
\end{tabular}

Note: $\quad$ Dependent variable: $L_{\mathrm{e}, \mathrm{i}, t} / L_{\mathrm{i}, \mathrm{t}}$ refers to the employment share for educational group $e$, industry $i$ at time $t$. Explanatory variables: (out $1_{\mathrm{i}, \mathrm{t}}$ ) refers to imports of intermediate goods from industry $i$ to industry $i$ relative to gross output. (out $2_{i, t}$ ) refers to imports of intermediate goods from manufacturing industries outside industry $i$ to industry $i$ relative to gross output. $\log (\mathrm{GO})$ refers to the $\log$ of gross output in total manufacturing. Technology change refers to lagged investment-specific technical change in industry $i$. All regressions include a first order autoregressive process (nor reported). $t$-statistics are White Heteroscedasticity consistent. ${ }^{* * *}$ significant at 1 pct. level, ${ }^{* *}$ significant at 5 pct. level, and ${ }^{*}$ significant at 10 pct. level.

Source: IDA, Statistics Denmark (2000), Cummins and Violante (2002) 